\title{
Hepatitis C virus core antigen, an earlier and stronger predictor on sustained virological response in patients with genotype $1 \mathrm{HCV}$ infection
}

Bo Feng ${ }^{1 \dagger}$, Rui-Feng Yang ${ }^{1 \dagger}$, Qing Xie², Jia Shang ${ }^{3}$, Fan-Yun Kong ${ }^{1}$, Hai-Ying Zhang ${ }^{1}$, Hui-Ying Rao ${ }^{1}$, Qian Jin , Xu Cong ${ }^{1}$, Yun-Ye Liư ${ }^{2}$, Yi Kang ${ }^{3}$ and Lai Wei ${ }^{*}$

\begin{abstract}
Background: Earlier kinetics of serum HCV core antigen (HCVCAg) and its predictive value on sustained virological response (SVR) were investigated in patients with genotype $1 \mathrm{HCV}$ infection during antiviral treatment.

Methods: In a multi-centered, randomized and positive drug-controlled phase Ilb clinical trial on type $Y$ peginterferon a-2b (NCT01140997), forty-eight CHC patients who participated in pharmacokinetics were randomly divided into 4 cohorts and treated with PegIFNa (type $Y$ peginterferon a-2b $90 \mu \mathrm{g}, 135 \mu \mathrm{g}, 180 \mu \mathrm{g}$ and PegIFNa-2a $180 \mu \mathrm{g}$, respectively, once a week) and ribavirin $(<75 \mathrm{~kg}, 1000 \mathrm{mg}$ daily and $\geq 75 \mathrm{~kg}, 1200 \mathrm{mg}$ daily) for 48 weeks, and then followed up for 24 weeks. 32 patients infected with genotype $1 \mathrm{HCV}$ and completed the whole process were included in this study. HCV RNAs were detected at baseline, and weeks 4, 12, 24, 48 and 72 using Cobas TaqMan. ARCHITECT HCVCAg was performed at 24, 48, 72, 96, 120 and $144 \mathrm{~h}$ in addition to the above time points. The receiver operating curves (ROCS) were performed to study the predictive values of HCVCAg decline on SVR.

Results: Following antiviral treatment, serum HCVcAg levels rapidly declined within the first week and correlated well with corresponding HCV RNA at baseline, weeks 4, 12, 24, 48 and $72\left(r_{s}=0.969,0.928,0.999,0.983,0.985\right.$ and 0.946 , respectively, $P<0.001$ ). All of the areas under the receiver operating curves (AUROCs) were more than 0.80 and showed good predictive power on SVR at 24, 48, 72, 96, 120 and $144 \mathrm{~h}$. The144 $\mathrm{h}$ was the best predictive time point of HCVCAg decline on SVR because of its largest AUROC (more than 0.90).

Conclusions: Early kinetics of serum HCVCAg predicts SVR very well in genotype $1 \mathrm{CHC}$ patients during antiviral treatment, and its reduction value at $144 \mathrm{~h}$ is an earlier and stronger predictor on SVR than rapid virological response and early virological response. (TRN: NCT01140997).
\end{abstract}

Keywords: Hepatitis C, HCV core antigen, Antiviral treatment, Interferon-a

\section{Background}

In the past 10 years, treatment response of chronic hepatitis $\mathrm{C}(\mathrm{CHC})$ has been increasingly improved based on the combination of pegylated interferon (PegIFN) $\alpha$ and ribavirin. The standard of care for newly diagnosed patients with hepatitis $\mathrm{C}$ virus ( $\mathrm{HCV}$ ), administered for

\footnotetext{
* Correspondence: weilai@pkuph.edu.cn

${ }^{\dagger}$ Equal contributors

'Peking University People's Hospital, Peking University Hepatology Institute, Beijing Key Laboratory of Hepatitis C and Immunotherapy for Liver Diseases, Beijing, PR China

Full list of author information is available at the end of the article
}

24 or 48 weeks, yielded sustained virological response (SVR) in approximately $80 \%$ and $40-50 \%$ of patients infected with HCV genotypes $2-3$ and 1, respectively [1]. However, about $50 \%$ genotype 1 chronic hepatitis C patients, who are the most common worldwide, do not achieve SVR. Additionally, besides expensive costs, almost all patients treated with PegIFNa and ribavirin experience one or more adverse events during the course of therapy [2]. As such, it is very important to predict the virological response patterns before and during anti-viral therapy.

\section{Ciomed Central}

(c) 2014 Feng et al.; licensee BioMed Central Ltd. This is an Open Access article distributed under the terms of the Creative Commons Attribution License (http://creativecommons.org/licenses/by/2.0), which permits unrestricted use, distribution, and reproduction in any medium, provided the original work is properly credited. The Creative Commons Public Domain Dedication waiver (http://creativecommons.org/publicdomain/zero/1.0/) applies to the data made available in this article, unless otherwise stated. 
Many factors, including virus, host and drugs, are associated with the response to IFN- $\alpha$-based therapy. Initial viral kinetics is most helpful in predicting treatment outcome. Patients who achieved a rapid virological response (RVR), which is defined as undetectable HCV RNA by Week 4 of therapy, are very likely to achieve SVR. By contrast, those who still have detectable HCV RNA levels by Week 12 of therapy have a very low likelihood of obtaining SVR [3,4]. As an illustration of the point which early viral responses are influenced by all pretreatment factors, once treatment has started, the IL28B genotype loses predictive value for SVR [5,6]. Treatment duration should be tailored to the virological response at weeks 4 and 12, and eventually week 24 . Treatment for all HCV genotypes should be stopped at week 12, if the HCV RNA decline is less than 2 $\log 10 \mathrm{IU} / \mathrm{ml}$ and at week 24, if HCV RNA is still detectable $(\geq 50 \mathrm{IU} / \mathrm{ml})$ [7]. That is to say, some patients do not know whether they need stopping antiviral treatment or keep going until week 24. Additionally, positive predictive value (PPV) of RVR is high, but its negative predictive value (NPV) is low. Marcellin et al. found that SVR can be achieved in $88 \%$ of patients with undetectable HCV RNA and $43 \%$ of those with detectable HCV RNA at week 4 [8]. Therefore, it is very important to search for a new marker for that will predict SVR earlier and more accurately.

Quantitative detection of $\mathrm{HCV}$ core antigen (HCVcAg) may be an alternative, which was reported to confirm viral replication in hepatitis $C$ infected patients $[9,10]$. Several studies showed that levels of serum $\mathrm{HCV} A \mathrm{Ag}$ correlate with those of HCV RNA in CHC patients [11-13]. In acute hepatitis $\mathrm{C}$ cases, $\mathrm{HCV}$ cAg can pick up a great majority of HCV RNA positive samples [14], and closely track $\mathrm{HCV}$ RNA dynamics throughout the course of the disease. Moreover, a sharp and parallel decrease of HCV RNA dynamics was observed during treatment with antiviral drugs 3 months after onset [15]. In the current study, based on a phase IIb clinical trial that examined the safety and efficacy of type Y pegylated interferon alfa-2b (NCT01140997, Pegabin ${ }^{\circ}$ Tebao Pharmaceuticals Inc., China) in $\mathrm{CHC}$ patients, we characterized dynamic changes of $\mathrm{HCV} c \mathrm{Ag}$ levels in patients with genotype $1 \mathrm{HCV}$ infection during antiviral treatment and investigated the predictive value of earlier kinetics of serum HCVcAg on SVR.

\section{Methods}

\section{Study design}

The clinical trial, based by the current study, was multicentered, randomized, open-labeled and used a positive drug-control on 210 naïve patients with HCV infection. The patients were randomly divided into 4 cohorts and treated with PegIFN $\alpha$ (type Y PegIFN $\alpha$-2b $90 \mu \mathrm{g}, 135 \mu \mathrm{g}$, $180 \mu \mathrm{g}$ and PegIFN $\alpha$-2a $180 \mu \mathrm{g}$, respectively, once a week) and ribavirin $(<75 \mathrm{~kg}, 1000 \mathrm{mg}$ daily and $\geq 75 \mathrm{~kg}, 1200 \mathrm{mg}$ daily) for 48 weeks, and then followed up for 24 weeks. Among all $48 \mathrm{CHC}$ patients who participated in pharmacokinetics, only those infected with genotype $1 \mathrm{HCV}$ and who completed the whole process were included in this study.

\section{Inclusion and exclusion criteria}

The patients ranged in age from 18 to 65 years old, had positive anti-HCV and HCV RNA levels of greater than $2000 \mathrm{IU} / \mathrm{ml}$ for at least six months, and also provided evidence of written informed consent. The study was approved by the ethical committees of Peking University People's Hospital, Peking University First Hospital, Beijing Friendship Hospital, 302 Hospital of People's Liberation Army, Beijing Youan Hospital, First Affiliated Hospital of Jilin University, Central-south University Xiangya Hospital, Sichuan University West China Hospital, Chongqing Medical University Second Affiliated Hospital, Fuzhou Infectious Disease Hospital, Guangzhou Eighth People's Hospital, Nangfang Hospital, the First Affiliated Hospital of Guangxi Medical Universtiy, the Second Affiliated Hospital of Harbin Medical University, the First Affiliated Hospital of Anhui Medical University, Jinan Infectious Disease Hospital, the First Affiliated Hospital of Lanzhou University, the First Affiliated Hospital of Nanchang University, 81 Military Hospital, Jiangsu Provincial People's Hospital, the Second Hospital of Nanjing, Changhai Hospital of Shanghai, Shanghai Public Health Clinical Center, Renji Hospital of Shanghai, 85 Hospital of People's Liberation Army, Ruijin Hospital of Shanghai, Huashan Hospital of Shanghai, Shenzhen Third People's Hospital, the Third Affiliated Hospital of Hebei Medical University, the First Affiliated Hospital of Shanxi University, Tianjin Third Central Hospital, the First Affiliated Hospital of Wenzhou Medical College, Huazhong Science and Technology University Tongji Hospital, Tangdu Hospital, the First Affiliated Hospital of Zhengzhou University and Henan Provincial People's Hospital. The study protocol conformed to the ethical guidelines of the 1975 Declaration of Helsinki, and was performed according to the guidelines of the International Conference on Harmonization for Good Clinical Practice. Exclusion criteria included significantly abnormal liver function (for example total bilirubin levels greater than 2 ULN, albumin levels lower than $35 \mathrm{~g} / \mathrm{L}$, PTA levels lower than $60 \%$ or evidence of decompensated liver disease and hepatocarcinoma), pregnancy or inability to practice adequate contraception, significant systemic or major illnesses other than liver disease, preexisting lower blood cells (white blood cell levels lower than $3 \times 10^{9} / \mathrm{L}$, absolute neutrocyte counts lower than $1.5 \times 10^{9} / \mathrm{L}$, platelet levels lower than $90 \times 10^{9} / \mathrm{L}$ and hemoglobin lower than lower limit of normal (LLN) or known history of antiviral or immunosuppressive therapy, and evidence of other viruses infection such as HAV, 
HBV, HEV, HIV, EBV and CMV. Liver injury caused by other agents was excluded, for example alcohol, drug, auto-immunity and metabolic abnormality among others.

\section{Lab examination}

HCV RNA levels were measured at baseline, at weeks 4, 12, 24, 48 and 72 of therapy. The COBAS AmpliPrep/ COBAS TaqMan automated real-time polymerase chain reaction (PCR) platform (Roche Molecular Systems, Pleasanton, CA) was used. This assay has a lower limit of detection (LLOD) of $15 \mathrm{IU} / \mathrm{mL}$ and a lower limit of quantification of $43 \mathrm{IU} / \mathrm{mL}$.

The ARCHITECT HCVcAg (Abbott Diagnostics, Wiesbaden, Germany), which is a quantitative chemiluminescent microparticle immunoassay and run on the fully automated ARCHITECT instrument, was used to quantify $\mathrm{HCV}$ cAg. As the manufacturer instructed, the assay was performed and $\mathrm{HCVcAg}$ levels lower than $3.0 \mathrm{fmol} / \mathrm{l}$ were considered nonreactive. $\triangle \mathrm{HCV} \mathrm{CAg}$ was defined as a $\log 10$ reduction of serum $\mathrm{HCVcAg}$ levels between other time points and baseline.

\section{Definitions}

SVR was defined as an undectable $\mathrm{HCV}$ RNA level ( $<50 \mathrm{IU} / \mathrm{ml}$ ), 24 weeks after cessation of treatment. RVR was defined as undetectable HCV RNA in a sensitive assay (lower limit of detection $\leq 50 \mathrm{IU} / \mathrm{ml}$ ) at week 4 of therapy and maintained up to the end of treatment [7]. The SVR corresponds to a cure of infection in $>99 \%$ of cases [16]. $\triangle \mathrm{HCV}$ cAg was defined as a $\log 10$ reduction of serum $\mathrm{HCV}$ cAg levels between other time points and baseline.

\section{Statistical analysis}

The statistical significance of differences between groups was analyzed by the student's $t$-test, one-way ANOVA, Fisher's exact test or the Mann-Whitney $U$-test. Correlation between HCVcAg and HCV RNA levels was measured using the Spearman's correlation coefficient. The optimal predictive values of $\triangle \mathrm{HCV} A \mathrm{Ag}$ and $\mathrm{HCV}$ cAg at different time points were assessed by calculating the areas under the univariate receiver operating characteristics (AUROC) curve. Sensitivity, specificity, PPV, and NPV were analyzed to determine the reliability of predictors of the response to therapy. All statistical analyses were performed with SPSS 16.0 (Chicago, IL, USA). Two-tailed $P$ values less than 0.05 were considered significant statistically.

\section{Results}

\section{Baseline characteristics of sample}

All thirty-two patients included in this study were infected with genotype $1 \mathrm{~b} \mathrm{HCV}$. There were 16 male and 16 female patients. The mean age was $45.16 \pm 11.06$. Mean baseline viral load and HCV antigen levels were
Table 1 Baseline patient characteristics for patients with sustained virological response (SVR) and non-sustained virological response (N-SVR)

\begin{tabular}{|c|c|c|c|}
\hline Parameters & SVR & N-SVR & $P$ \\
\hline Male/female & $10 / 6$ & $6 / 10$ & 0.325 \\
\hline Age (years) & $41.90 \pm 11.08$ & $51.36 \pm 8.31$ & 0.019 \\
\hline $\mathrm{ALT}(\mathrm{U} / \mathrm{L})$ & $47.38 \pm 3.65$ & $47.27 \pm 6.87$ & 0.988 \\
\hline HCV RNA (log10 IU/mL) & $6.39 \pm 0.57$ & $6.21 \pm 1.14$ & 0.557 \\
\hline HCVCAg $(\log 10 \mathrm{fmol} / \mathrm{L})$ & $3.61 \pm 0.54$ & $3.75 \pm 0.36$ & 0.441 \\
\hline No. of each cohorts ${ }^{a}$ & $6 / 3 / 7 / 5$ & $2 / 6 / 2 / 1$ & 0.057 \\
\hline
\end{tabular}

${ }^{\mathrm{a}}$ The numbers of patients in each cohorts (Y PeglFN a-2b $90 \mu \mathrm{g}, 135 \mu \mathrm{g}$, $180 \mu \mathrm{g}$, and PegIFNa-2a $180 \mu \mathrm{g}$ ).

$6.33 \pm 0.88 \log 10 \mathrm{IU} / \mathrm{mL}$ and $3.66 \pm 0.49 \log 10 \mathrm{fmol} / \mathrm{L}$, respectively. Based on the outcomes, these patients were divided into SVR and non-SVR groups, of which the baseline characteristics are described below (Table 1). There were no differences between SVR and non-SVR groups in baseline parameters including gender, ALT, HCV RNA, HCVcAg, dose and category of PegIFNa and excluding age.

\section{Dynamic changes of HCVcAg levels during antiviral treatment}

Following antiviral treatment, serum $\mathrm{HCV}$ cAg levels closely track those of HCV RNA and rapidly declined within the first 4 weeks (Figure 1). At baseline, week 4, 8, 12, 24, 48 and 72, HCVcAg levels showed excellent correlation with HCV RNA; spearman correlation coefficients were $0.956,0.937,0.999,0.983,0.995$ and 0.980 , respectively $(P<0.001)$.

Predictive values of $\triangle \mathrm{HCV}$ cAg on SVR at various time points of the first 12 weeks of treatment

To investigate the predictive values of $\triangle \mathrm{HCVcAg}$ at various time points within the first 12 weeks on SVR and to

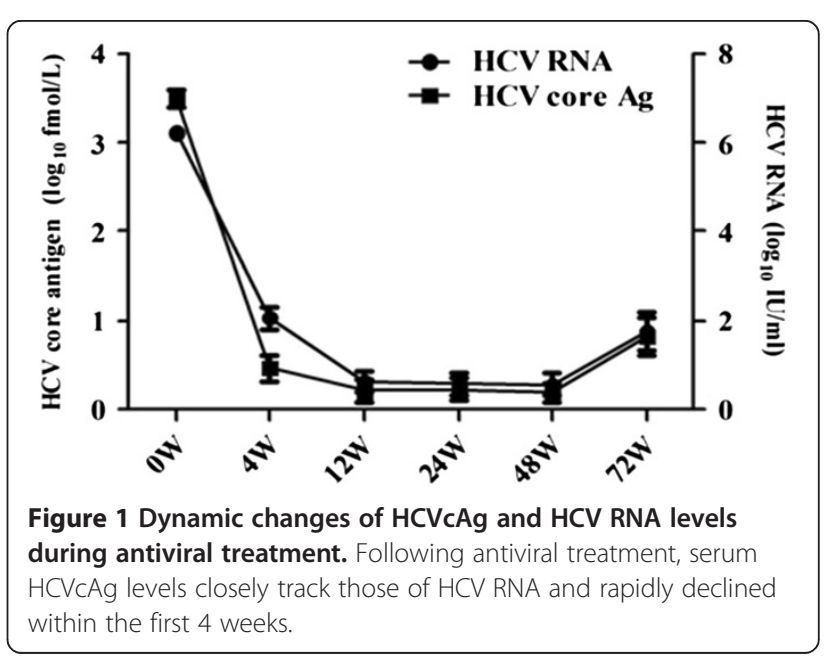


search for the best cutoff values, ROCs were performed (Figure 2). Based on these ROCs, important parameters were worked out including AUROC, the optimal cutoff values, sensitivity, specificity, PPV and NPV (Table 2). AUROCs were $0.835,0.814,0.870,0.866,0.879,0.913$,
0.853, 0.823 and 0.719 at $24 \mathrm{~h}, 48 \mathrm{~h}, 72 \mathrm{~h}, 96 \mathrm{~h}, 120 \mathrm{~h}$ and $144 \mathrm{~h}$, and at weeks 4,8 and 12 . The highest AUROC was 0.913 at $144 \mathrm{~h}$. At $24 \mathrm{~h}, 48 \mathrm{~h}, 72 \mathrm{~h}, 96 \mathrm{~h}$, $120 \mathrm{~h}$ and $144 \mathrm{~h}$, and at week 4 , cutoff values, which predicted SVR, were $0.785,1.090,1.034,1.262,1.138$,
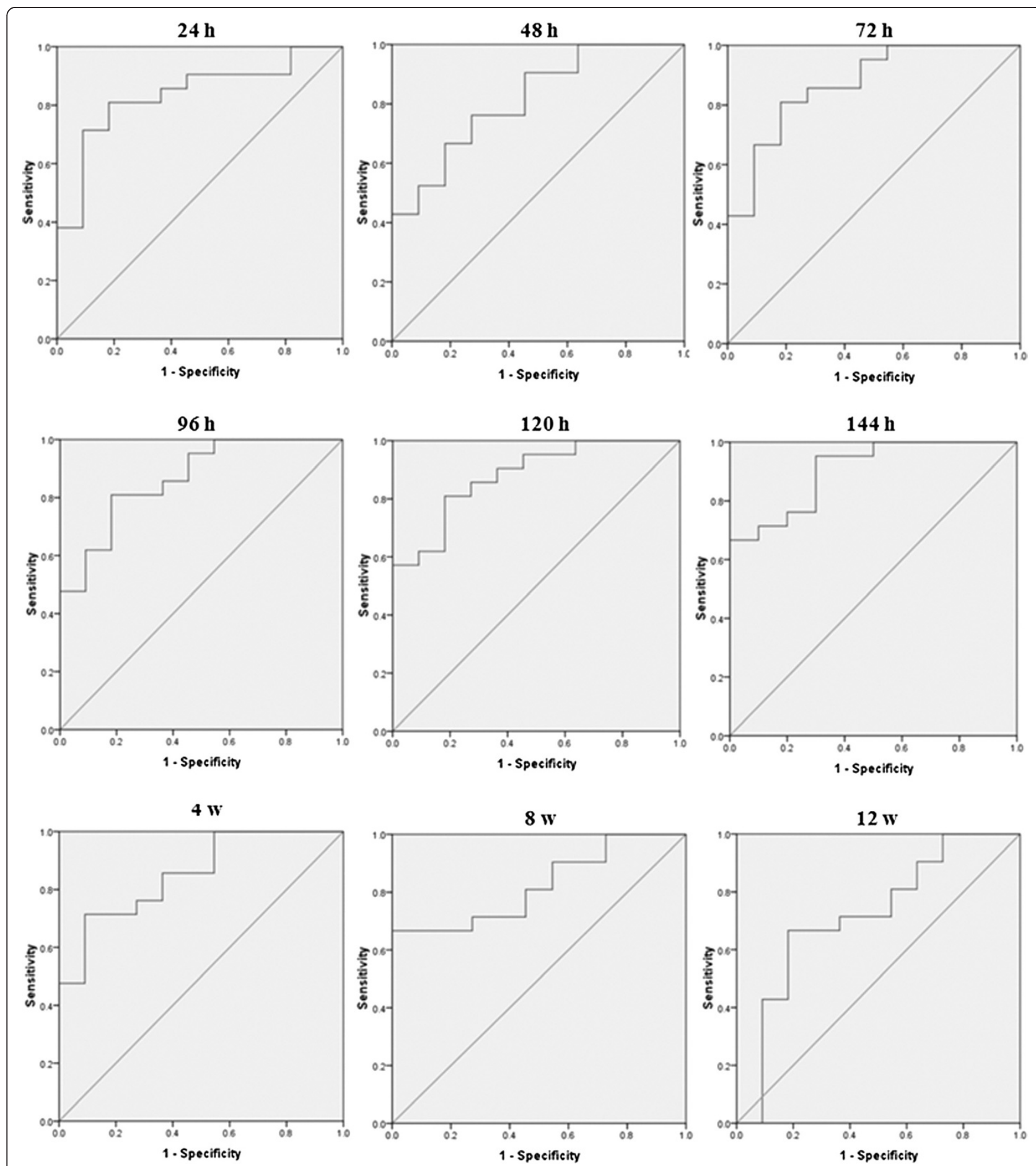

Figure 2 ROCs of predictive values of $\triangle \mathrm{HCV}$ cAg at various time points of the first 12 weeks on SVR. AUROCs calculated were $0.835,0.814$, $0.870,0.866,0.879,0.913,0.853,0.823$ and 0.719 at 24 h, 48 h, 72 h, 96 h, 120 h, 144 h, and weeks 4, 8, 12. 
Table 2 Area under the ROC curve (AUROC), sensitivity, specificity, and predictive values of sustained virological response based on a log 10 decrease in total HCV core antigen, across cutpoints and timepoints after initial antiviral treatment

\begin{tabular}{|c|c|c|c|c|c|c|c|c|c|c|}
\hline & $24 \mathrm{~h}$ & $48 \mathrm{~h}$ & $72 \mathrm{~h}$ & $96 \mathrm{~h}$ & $120 \mathrm{~h}$ & $144 \mathrm{~h}-1$ & $144 \mathrm{~h}-2$ & $4 w$ & $8 w$ & $12 \mathrm{w}$ \\
\hline AUROC & 0.835 & 0.814 & 0.870 & 0.866 & 0.879 & 0.913 & 0.913 & 0.853 & 0.823 & 0.719 \\
\hline$(95 \%$ Cl) & $(0.691-0.980)$ & $(0.663-0.965)$ & $(0.742-0.998)$ & $(0.738-0.994)$ & $(0.760-0.998)$ & $(0.799-1.000)$ & $(0.799-1.000)$ & $(0.720-0.985)$ & $(0.680-0.965)$ & $(0.520-0.917)$ \\
\hline Cutoffa & 0.785 & 1.090 & 1.034 & 1.262 & 1.138 & 0.976 & 1.096 & 3.231 & 3.780 & 3.770 \\
\hline Sensitivity & 0.810 & 0.762 & 0.810 & 0.810 & 0.810 & 0.952 & 0.762 & 0.714 & 0.667 & 0.667 \\
\hline Specificity & 0.818 & 0.727 & 0.818 & 0.818 & 0.818 & 0.700 & 0.800 & 0.909 & 1.000 & 0.818 \\
\hline PPV & 1.000 & 1.000 & 1.000 & 1.000 & 1.000 & 0.913 & 1.000 & 1.000 & 1.000 & 1.000 \\
\hline NPV & 0.846 & 0.846 & 0.846 & 0.846 & 0.846 & 1.000 & 0.769 & 0.687 & 0.611 & 0.687 \\
\hline
\end{tabular}

AUROC, areas under the univariate receiver operating characteristic curve; PPV, positive predictive value; NPV, negative predictive value.

${ }^{a}$ Cutoff was defined as change of log $10 \mathrm{fmol} / \mathrm{L}$.

1.096 and 3.231; the corresponding sensitivity was 0.810 , $0.762,0.810,0.810,0.818,0.762$ and 0.714 ; specificity was 0.818, 0.727, 0.818, 0.818, 0.818, 0.800 and 0.909; PPVs were $1.000,1.000,1.000,1.000,1.000,1.000$ and 1.000; and NPVs were $0.846,0.846,0.846,0.846,0.846,0.769$ and 0.688 , respectively. While PPVs were similar across time points, NPVs differed. The optimal combination of AUROC, PPV and NPV, with a cutoff value of 0.976 was at 144 h, with AUROC 0.913, PPV of 0.913 and NPV 1.000.

\section{Predictive power of HCVCAg on SVR at various time} points of the first week of the treatment

Predictive values of $\mathrm{HCVCAg}$ on SVR were measured using by AUROCs at $24 \mathrm{~h}, 48 \mathrm{~h}, 72 \mathrm{~h}, 96 \mathrm{~h}, 120 \mathrm{~h}$ and $144 \mathrm{~h}$. The corresponding AUROCs were 0.236, 0.225, $0.195,0.186,0.182$ and 0.126 at these various time

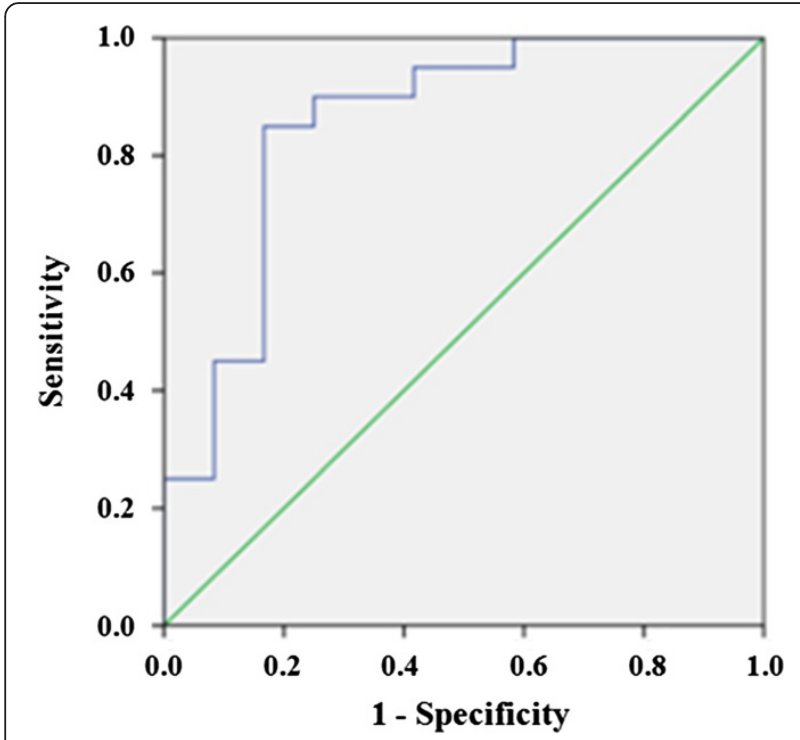

Figure 3 ROC curves of predictive values of HCV RNA at week 4 on sustained virological response (SVR). When the optimal cutoff value was 3.770, the corresponding AUROC was 0.854 (95\% Cl 0.705-1.000). points, respectively. This showed that the absolute values of $\mathrm{HCV}$ cAg levels had no predictive power on SVR in genotype $1 \mathrm{HCV}$ infected patients.

Predictive value of HCV RNA decline at week 4 of the treatment on SVR

ROC was performed on the basis of the relationship between $\triangle$ HCV RNA at week 4 and SVR (Figure 3). When the cutoff value was 3.770 , the corresponding AUROC, sensitivity, specificity, PPV and NPV were 0.854 (95\% CI 0.705-1.003), $0.850,0.833,1.000$ and 0.706 . Calculated sensitivity, specificity, accuracy, PPV and NPV of RVR were $0.229,1.000$, $0.500,1.000$ and 0.407 . Table 3 showed the results comparing the predictive value of $\triangle \mathrm{HCVcAg}$ at $144 \mathrm{~h}$, and weeks 4 , 8 , and 12 to that of $\triangle \mathrm{HCV}$ RNA at week 4 . Results indicated comparable PPVs, both 100\%, but higher NPV (76.9\%) and higher AUROC (0.913) for HCVcAg at $144 \mathrm{~h}$ compared to HCV RNA at week 4 (70.6\%, 0.854) respectively.

Comparison of predictive power between a $\log _{10}$ decrease in HCVCAg at $144 \mathrm{~h}$ and RVR/EVR

As for the 32 patients included in this study, the parameters of predictive value of a $\log _{10}$ decrease in $\mathrm{HCVcAg}$

Table 3 Predictive values and Area under the ROC curve (AUROC) of sustained virological response based on a log 10 decrease in total HCV core antigen and HCV RNA concentrations after initial antiviral treatment

\begin{tabular}{lccc}
\hline & PPV & NPV & AUROC (95\% Cl) \\
\hline SHCVCAg $(\log 10 \mathrm{fmol} / \mathrm{L})$ & & & \\
144 h & $100 \%$ & $76.9 \%$ & $0.913(0.799-1.000)$ \\
Week 4 & $100 \%$ & $68.7 \%$ & $0.853(0.720-0.985)$ \\
Week 8 & $100 \%$ & $61.1 \%$ & $0.823(0.680-0.965)$ \\
Week 12 & $100 \%$ & $68.7 \%$ & $0.719(0.520-0.917)$ \\
AHCV RNA (log10 IU/mL) & & & \\
Week 4 & $100 \%$ & $70.6 \%$ & $0.854(0.705-1.000)$ \\
\hline
\end{tabular}

PPV, positive predictive value; NPV, negative predictive value; AUROC, areas under the univariate receiver operating characteristic curve. 
Table 4 Comparison of predictive power of a $\log _{10}$ decrease in $\mathrm{HCV}$ cAg at $144 \mathrm{~h}$ and rapid virological response (RVR)/early virological response (EVR)

\begin{tabular}{lccccc}
\hline & Sensitivity & Specificity & Accuracy & PPV & NPV \\
\hline$\triangle H C V ~ A g \geq 1 \log$ & 0.952 & 0.727 & 0.875 & 0.870 & 0.889 \\
RVR & 0.286 & 1.000 & 0.531 & 1.000 & 0.423 \\
EVR & 1.000 & 0.273 & 0.750 & 0.724 & 1.000 \\
\hline
\end{tabular}

at $144 \mathrm{~h}, \mathrm{RVR}$ and early virological response (EVR) were calculated (Table 4). RVR had higher specificity (1.000) and PPV (1.000), and EVR has higher sensitivity (1.000) and NPV (1.000). Conversely, sensitivity and NPV of RVR, and specificity and PPV of EVR were lower. The accuracy of RVR and EVR was lower than a $\log _{10}$ decrease of HCVCAg at $144 \mathrm{~h}$.

Influence of baseline parameters on $\triangle \mathrm{HCV}$ cAg at $144 \mathrm{~h}$

As indicated in Figure 4, a decline of HCVcAg at $144 \mathrm{~h}$ showed a correlation with age $\left(r_{s}=-0.583, P<0.001\right)$, and no correlation with baseline viral loads and HCVcAg levels $(P=0.107$ and $P=0.288$, respectively). Additionally, gender, dose and category of PegIFNa had no effect on $\triangle \mathrm{HCVcAg}$ at $144 \mathrm{~h}(P=0.276, P=0.458$ and $P=0.623$, respectively).

\section{Discussion}

Several assays are used in the screening, diagnosis and management of $\mathrm{HCV}$ infection: detection of specific antibody to $\mathrm{HCV}$ and HCV RNA, and HCV genotyping $[17,18]$. So far, the early dynamic change of HCV nucleic acid levels, which are direct proof of viral replication, is a very important marker in predicting antiviral response patterns in $\mathrm{CHC}$ patients. As a gold standard, the kinetics of HCV RNA has been widely used in response-guided and individual therapy. Conjeevaram et al. thought that viral kinetics provide a summative reflection of the baseline factors, including insulin resistance, gender, age and genetic polymorphisms, which are involved in transducing the response to these agents [19]. However, as described above, nucleic acid quantitative detection of LOD of $50 \mathrm{IU} / \mathrm{mL}$ has some limitations, especially in developing countries.

The first assay for HCVcAg was developed in 1999 [20]. Now sensitivity and specificity of quantitative $\mathrm{HCVcAg}$ assay has been increasingly improved. The Architect HCVcAg assay (Abbott Diagnostics), with a dynamic range of quantification $(3.0-20,000 \mathrm{fmol} / \mathrm{L})$, is commercially available. It shows a good correlation with $\mathrm{HCV}$ RNA in various $\mathrm{CHC}$ populations including $\mathrm{HCV}$ monoinfection, $\mathrm{HCV} / \mathrm{HIV}$ and $\mathrm{HCV} / \mathrm{HBV}$ coinfection, and can reflect viral replication as HCV RNA does [21]. Here, similar changes of HCVcAg and HCV RNA were observed during PegIFN $\alpha$ combined with ribavirin treatment in genotype $1 \mathrm{HCV}$ infected patients. Good correlations were showed between serum HCVcAg and $\mathrm{HCV}$ RNA levels at various time points observed in this study. Moreover, serum HCVcAg levels declined sharply in the first 4 weeks after treatment was initiated.

By calculating the AUROCs, we assessed the optimal predictive values of $\triangle \mathrm{HCVCAg}$ at 24, 48, 72, 96, 120 and $144 \mathrm{~h}$ on SVR. We found that all of AUROCs were more than 0.80 and showed good predictive power at various time points in the first week. The second injection was performed at $168 \mathrm{~h}$. We selected $144 \mathrm{~h}$, which had the largest AUROC (0.913) as the best predictive time point. On the other hand, for obtaining the highest sensitivity and NPV, the lowest cutoff was obtained at quartile 0.25. Conversely, for obtaining the highest specificity and PPV, the highest cutoff was obtained at quartile 0.75 . So, we selected 0.976 and 1.096 as cutoff values of $144 \mathrm{~h}$, which both had a corresponding NPV and PPV of 1.000. That is, at the $144 \mathrm{~h}$ time point it will be unlikely that patients will have a $\triangle \mathrm{HCVCAg}$ lower than 0.976 and those patients with a $\triangle \mathrm{HCVCAg}$ of more than 1.096 will be likely to achieve SVR. On the other hand, if the $\triangle \mathrm{HCV}$ cAg at $144 \mathrm{~h}$ is between 0.976 and 1.096 , the corresponding NPV and PPV will be at least 0.769 and 0.913 , respectively.
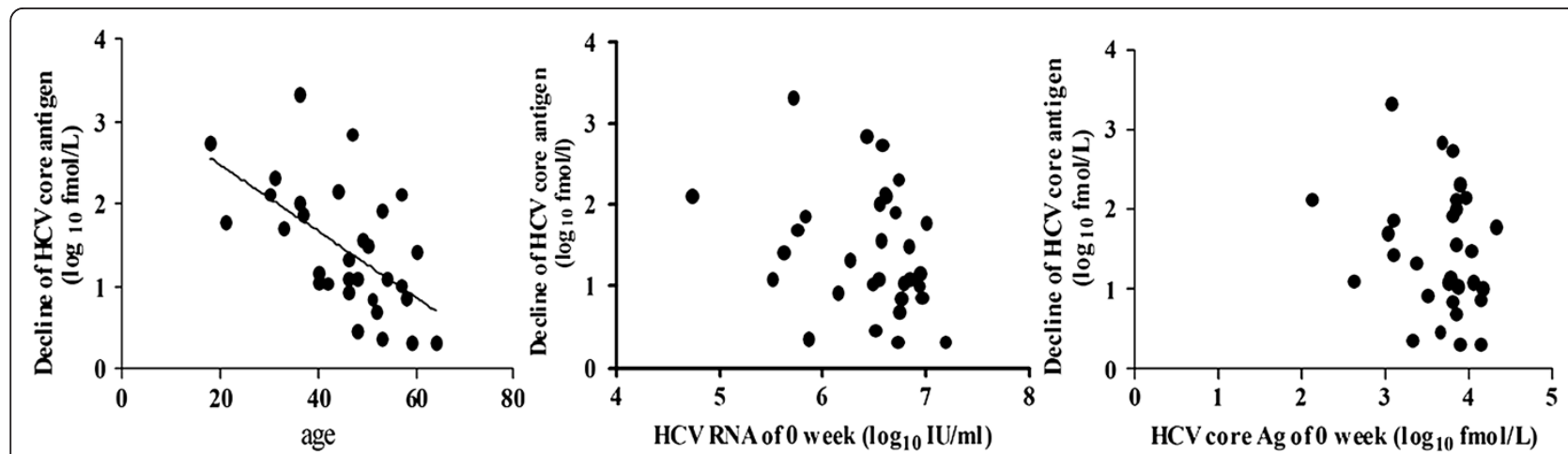

Figure 4 Influence of baseline parameters on $\triangle \mathrm{HCV}$ cAg at $144 \mathrm{~h}$. Decline of HCVCAg at $144 \mathrm{~h}$ showed a correlation with age $\left(r_{5}=-0.583\right.$, $P<0.001)$, and no correlation with baseline viral loads and HCVcAg levels $(P=0.107$ and $P=0.288$, respectively). 
HCVcAg and HCV RNA have been shown to have a strong correlation $(r=0.86)$, from a sample where plasma $\mathrm{HCV}$ antigen was detected in 51 of 54 patients with an interpolated LOD cut off between $10^{3}$ and $10^{4}$ RNA IU/mL [22]. Chevaliez et al. thought the current assays for detecting $\mathrm{HCVcAg}$ are not suitable for monitoring changes of $\mathrm{HCV}$ replication power during antiviral therapy and response-guided therapy [10]. However, the hypothesis has never been proven in clinical practice. In the current study, we analyzed the predictive power of $\triangle \mathrm{HCV}$ RNA at week 4 and RVR on SVR by ROC. The AUROC of $\triangle \mathrm{HCV}$ RNA at week 4 was lower than that of $\triangle \mathrm{HCV}$ cAg at $144 \mathrm{~h}$. RVR which accuracy was $50 \%$ had higher PPV and lower NPV. We thought that the sensitivity of HCVcAg detection may be lower than that of $\mathrm{HCV}$ RNA when confirming viral replication and active infection, but HCVcAg may actually be more meaningful in reflecting dynamic changes of viral replication and in predicting SVR earlier during double treatment. If proven true by larger patient samples, $\mathrm{HCV}$ cAg detection will be more promising in clinical practice because it is less expense and easier to perform, especially in areas with limited resources.

As we well know, many baseline parameters including virus, host and drug factors are associated with response to IFN- $\alpha$-based therapy. In the current study, we found that patient gender, dose and category of PegIFNa, baseline viral loads and $\mathrm{HCV}$ cAg levels had no correlation with $\triangle \mathrm{HCVcAg}$ at $144 \mathrm{~h}$, except for age. Further investigation should be performed to determine whether it is true or limited by numbers of patients. On the other hand, we did not differentiate null responders and relapsers because of limited receivers.

\section{Conclusions}

Serum HCVcAg is a good marker for reflecting dynamic changes of $\mathrm{HCV}$ viremia in genotype $1 \mathrm{CHC}$ patients during PegIFNa when combined with ribavirin treatment. Following antiviral treatment, serum $\mathrm{HCVcAg}$ levels rapidly declined within the first week similar to HCV RNA. All of the AUROCs were more than 0.80 and showed good predictive power on SVR at 24, 48, 72, 96, 120 and $144 \mathrm{~h} .144 \mathrm{~h}$ was selected as the best predictive time point because of its largest AUROC (more than 0.90). 0.976 and 1.096 were selected as cutoff values of 144 h; both have a corresponding NPV and PPV of 1.000. Moreover, the predictive value of $\triangle \mathrm{HCVcAg}$ at $144 \mathrm{~h}$ is better than that of $\triangle \mathrm{HCV}$ RNA and negative HCV RNA at week 4 .

\section{Abbreviations}

CHC: Chronic hepatitis C; PegIFN: Pegylated interferon; HCV: Hepatitis C virus; SVR: Sustained virological response; RVR: Rapid virological response; PPV: Positive predictive value; NPV: Negative predictive value; HCVCAg: HCV core antigen; LLN: Lower limit of normal; HAV: Hepatitis A virus;
HBV: Hepatitis B virus; HEV: Hepatitis E virus; HIV: Human immunodeficiency virus; EBV: Epstein-Barr virus; CMV: Cytomegalovirus; PCR: Polymerase chain reaction; LLOD: Lower limit of detection; AUROC: Areas under the univariate receiver operating characteristic curve.

\section{Competing interests}

This study was sponsored in part by Xiamen Amoytop Biotech Co., Ltd.

\section{Authors' contributions}

BF and RFY contributed to study design, experimental process, data acquisition, statistical analysis and drafted the manuscript. FYK and HYZ contributed to experimental process, data acquisition, and statistical analysis. YK contributed to experimental process and drafted the manuscript. HYR and YYL participated in study planning and statistical analysis. QJ and XC contributed to study design, data analysis, and drafted the manuscript. LW, QX and JS participated in design, funding analysis and manuscript drafting. All authors read and approved the final manuscript.

\section{Acknowledgements}

This study was supported by National S\&T Major Project for Infectious Diseases Control (grant no. 2012ZX10002-003), National Major S\&T Special Project for "Significant New Drugs Development" (grant no. 2012ZX09303-019), and Beijing Natural Science Foundation (grant no. 7122191).

\section{Author details}

'Peking University People's Hospital, Peking University Hepatology Institute, Beijing Key Laboratory of Hepatitis C and Immunotherapy for Liver Diseases, Beijing, PR China. ${ }^{2}$ Department of Infectious Diseases, Ruijin Hospital, Shanghai Jiao Tong University School of Medicine, Shanghai, PR China. ${ }^{3}$ Department of Infectious Diseases, Henan Provincial People's Hospital, Zhengzhou, PR China.

Received: 30 December 2013 Accepted: 24 February 2014 Published: 13 March 2014

\section{References}

1. Sarrazin C, Hezode C, Zeuzem S, Pawlotsky JM: Antiviral strategies in hepatitis C virus infection. J Hepatol 2012, 56(Suppl 1):S88-S100.

2. Ghany MG, Strader DB, Thomas DL, Seeff LB: Diagnosis, management, and treatment of hepatitis C: an update. Hepatology 2009, 49(4):1335-1374.

3. Jacobson IM, McHutchison JG, Dusheiko G, Di Bisceglie AM, Reddy KR, Bzowej NH, Marcellin P, Muir AJ, Ferenci P, Flisiak R, George J, Rizzetto M, Shouval D, Sola R, Terg RA, Yoshida EM, Adda N, Bengtsson L, Sankoh AJ, Kieffer TL, George S, Kauffman RS, Zeuzem S, ADVANCE Study Team: Telaprevir for previously untreated chronic hepatitis $C$ virus infection. N Engl J Med 2011, 364(25):2405-2416.

4. Poordad F, McCone J Jr, Bacon BR, Bruno S, Manns MP, Sulkowski MS, Jacobson IM, Reddy KR, Goodman ZD, Boparai N, DiNubile MJ, Sniukiene V, Brass CA, Albrecht JK, Bronowicki JP, SPRINT-2 Investigators: Boceprevir for untreated chronic HCV genotype 1 infection. N Engl J Med 2011, 364(13):1195-1206.

5. Mangia A, Thompson AJ, Santoro R, Piazzolla V, Copetti M, Minerva N, Petruzzellis D, Mottola L, Bacca D, McHutchison JG: Limited use of interleukin $28 \mathrm{~B}$ in the setting of response-guided treatment with detailed on-treatment virological monitoring. Hepatology 2011, 54(3):772-780.

6. Thompson AJ, Muir AJ, Sulkowski MS, Ge D, Fellay J, Shianna KV, Urban T, Afdhal NH, Jacobson IM, Esteban R, Poordad F, Lawitz EJ, McCone J, Shiffman ML, Galler GW, Lee WM, Reindollar R, King JW, Kwo PY, Ghalib RH, Freilich B, Nyberg LM, Zeuzem S, Poynard T, Vock DM, Pieper KS, Patel K, Tillmann HL, Noviello S, Koury K, Pedicone LD, Brass CA, Albrecht JK, Goldstein DB, McHutchison JG: Interleukin-28B polymorphism improves viral kinetics and is the strongest pretreatment predictor of sustained virologic response in genotype 1 hepatitis C virus. Gastroenterology 2010, 139(1):120-129.

7. European Association for the Study of the Liver: EASL clinical practice guidelines: management of hepatitis C virus infection. J Hepatol 2011, 55(2):245-264.

8. Marcellin $P$, Reau N, Ferenci $P$, Hadziyannis $S$, Messinger D, Tatsch F, Jensen D: Refined prediction of week 12 response and SVR based on week 4 response 
in HCV genotype 1 patients treated with peginterferon alfa-2a (40KD) and ribavirin. J Hepatol 2012, 56(6):1276-1282.

9. Mederacke I, Wedemeyer H, Ciesek S, Steinmann E, Raupach R, Wursthorn K, Manns MP, Tillmann HL: Performance and clinical utility of a novel fully automated quantitative HCV-core antigen assay. J Clin Virol 2009, 46(3):210-215.

10. Chevaliez S, Rodriguez C, Pawlotsky JM: New virologic tools for management of chronic hepatitis B and C. Gastroenterology 2012, 142(6):1303-1313

11. Park Y, Lee JH, Kim BS, Kim do Y, Han KH, Kim HS: New automated hepatitis $\mathrm{C}$ virus (HCV) core antigen assay as an alternative to real-time PCR for HCV RNA quantification. J Clin Microbiol 2010, 48(6):2253-2256.

12. Hosseini-Moghaddam S, Iran-Pour E, Rotstein C, Husain S, Lilly L, Renner E, Mazzulli T: Hepatitis $C$ core $\mathrm{Ag}$ and its clinical applicability: potential advantages and disadvantages for diagnosis and follow-up? Rev Med Virol 2012, 22(3):156-165.

13. Descamps V, Op de Beeck A, Plassart C, Brochot E, François C, Helle F, Adler M, Bourgeois N, Degré D, Duverlie G, Castelain S: Strong correlation between liver and serum levels of hepatitis $C$ virus core antigen and RNA in chronically infected patients. J Clin Microbiol 2012, 50(2):465-468.

14. Yuksel P, Caliskan R, Ergin S, Aslan M, Celik DG, Saribas S, Ziver T, Yalciner A, Kocazeybek B: New approaches to in vitro diagnosis of hepatitis $C$ infection a reason for post transfusion hepatitis: diagnostic value of determination of hepatitis C virus core antigen. Transfus Apher Sci 2011, 45(3):247-250

15. Medici MC, Furlini G, Rodella A, Fuertes A, Monachetti A, Calderaro A, Galli S, Terlenghi L, Olivares M, Bagnarelli P, Costantini A, De Conto F, Sainz M, Galli C, Manca N, Landini MP, Dettori G, Chezzi C: Hepatitis C virus core antigen: analytical performances, correlation with viremia and potential applications of a quantitative, automated immunoassay. J Clin Virol 2011, 51(4):260-265.

16. Swain MG, Lai MY, Shiffman ML, Cooksley WG, Zeuzem S, Dieterich DT, Abergel A, Pessôa MG, Lin A, Tietz A, Connell EV, Diago M: A sustained virologic response is durable in patients with chronic hepatitis $C$ treated with peginterferon alfa-2a and ribavirin. Gastroenterology 2010, 139(5):1593-1601.

17. Yousaf MZ, Idrees M, Saleem Z, Rehman IU, Ali M: Expression of core antigen of HCV genotype 3a and its evaluation as screening agent for HCV infection in Pakistan. Virol J 2011, 8:364.

18. Idrees M, Rehman IU, Manzoor S, Akbar H, Butt S, Afzal S, Yousaf MZ, Hussain A: Evaluation of three different hepatitis $C$ virus typing methods for detection of mixed genotype infections. J Dig Dis 2011, 12(3):199-203.

19. Conjeevaram HS, Kleiner DE, Everhart JE, Hoofnagle JH, Zacks S, Afdhal NH, Wahed AS, Virahep-C Study Group: Race, insulin resistance and hepatic steatosis in chronic hepatitis C. Hepatology 2007, 45(1):80-87.

20. Aojagy K, Ohue C, Lida K, Kimura T, Tanaka E, Kiyosawa K, Yagi S: Development of a simple and highly sensitive enzyme immunoassay for hepatitis C virus core antigen. J Clin Microbiol 1999, 37(6):1802-1808.

21. Mederacke I, Potthoff A, Meyer-Olson D, Meier M, Raupach R, Manns MP, Wedemeyer $\mathrm{H}$, Tillmann HL: HCV core antigen testing in HIV- and HBV-coinfected patients, and in HCV-infected patients on hemodialysis. J Clin Virol 2012, 53(2):110-115.

22. Tedder RS, Tuke P, Wallis N, Wright M, Nicholson L, Grant PR: Therapyinduced clearance of HCV core antigen from plasma predicts an end of treatment viral response. J Viral Hepat 2013, 20(1):65-71.

\section{doi:10.1186/1471-230X-14-47}

Cite this article as: Feng et al: Hepatitis C virus core antigen, an earlier and stronger predictor on sustained virological response in patients with genotype 1 HCV infection. BMC Gastroenterology 2014 14:47.

\section{Submit your next manuscript to BioMed Central and take full advantage of:}

- Convenient online submission

- Thorough peer review

- No space constraints or color figure charges

- Immediate publication on acceptance

- Inclusion in PubMed, CAS, Scopus and Google Scholar

- Research which is freely available for redistribution

Submit your manuscript at www.biomedcentral.com/submit
Ciomed Central 